\title{
Evaluation Of Integrated Learning Implementation In Percuthigh School, Sei Tuan, Medan
}

\author{
Devi Herlina Tarigan ${ }^{1}$, Billian Jawadi Lubis ${ }^{2}$, Lestari Perangin nangin ${ }^{3}$, Tiurmauli ${ }^{4}$, \\ Dameria Sihite ${ }^{5}$ \\ \{dev89tarigan@gmail.com¹, jawadilubis@yahoo.com², lestarinangin2016@gmail.com³ \\ tiurmaulipakam@gmail.com ${ }^{4}$, dameriasihite151261@gmail.com ${ }^{5}$ \}
}

Postgraduate Program, Pelita Kebenaran School of Theology,12,3,4,5

\begin{abstract}
Learning is a process characterized by a change in a person where these changes are the result of the learning process, such as changes in knowledge, understanding, attitudes and behavior, skills, abilities and abilities, the power of reaction, the power of acceptance and so forth that exist in individuals. Learning in the view of the 2003 National Education Law Chapter I Article 1 is "the process of interaction between students and educators and learning resources in a learning environment". Therefore, learning is an activity involving educators and students that contain two elements, namely teaching and learning. Learning is also known as the teaching and learning process and integrated learning is an approach used in learning activities by integrating activities into all fields of development, including cognitive, social-emotional, language, moral, and religious, physical motor and art aspects. It is expected that these activities can allow children to integrate their knowledge and skills from experience to other experiences, so that students have the opportunity to optimally develop all their potential. Learning itself is a process, which is based on the base word 'learn'; thus learning is basically the process of change in one's life.
\end{abstract}

Keywords: Integrated learning, evaluation of learning

\section{Introduction}

Education is considered successful if students can apply what they are taught. In order to be able to carry out education in accordance with the expectations, learning strategies are needed. An effective learning strategy is integrated learning. This form of learning is also characterized by various methods or models. Essentially integrated learning hopes that students can be active both individually and in groups. Integrated learning is a learning strategy that expects students to gain direct experience, adding capability to receive, store, and apply the concepts that have been learned. The result is that students become trained to find the concepts learned, meaningful, authentic and active. However, based on observations, many students lack experience in learning, causing them to experience a decrease in interest in learning, thinking power, independence, and easily become affected by negative things from the environment or the current technological era. Even though it can be possible for these things to happen because of internal factors, further research is needed to investigate students' respective personalities. From the problems faced by students drawn from the results of these observations, it is necessary to look at the learning strategies carried out in the classroom. Is the strategy adequate for students? Or are educators not able to master the strategies they use in the learning they do in 
the classroom? If the answer is 'negative' for these questions, it can be ascertained that there is an error in the learning process, whether it is in the strategy or in the educator (teacher).

Therefore it is necessary to understand that the existence of integrated learning, which is one model or strategy in learning, is actually not difficult, but it is not too easy. Because the core of all learning models requires the name of the educator's skills in processing it into effective learning. And to answer the problems described above from observations made, integrated learning can be a good alternative to be applied in school learning activities. Because this integrated learning prioritizes direct experience to students, so that students can search, explore, and discover scientific concepts and principles that are holistic, meaningful, and authentic so students (students) can apply their learning to solve real problems in everyday life.
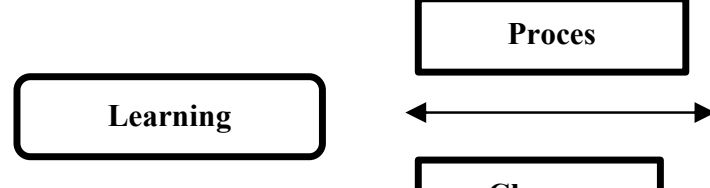

\section{Change}

Figure 1. Learning is a process of change in life

Therefore it is necessary to understand that the existence of integrated learning, which is one model or strategy in learningthat is actually not difficult, but also not too easy as the core of all learning models requires the educator's skills in processing it into effective learning. To answer the problems described above from observations made, integrated learning can be a good alternative to be applied in school learning activities. Because integrated learning prioritizes direct experience to students, students can search, explore, and discover scientific concepts and principles that are holistic, meaningful, and authentic, allowing them to apply their learning to solve real problems in everyday life. Thus integrated learning invites students to be active both individually and in groups. The concept of integrated learning is to bring up an understanding of some material that has been integrated so as to produce a new perspective called theme. The theme is a combination of several subjects. For example, after combining science and social studies, a theme is chosen that can combine the two. For the theme of flood in science material is collected about reforestation or can be taken from social studies with material studying the shape of the land or its geographical location. After this students find and produce their own learning and are able to express what is gained from the learning. See Figure 2 below to understand the integrated learning process carried out.

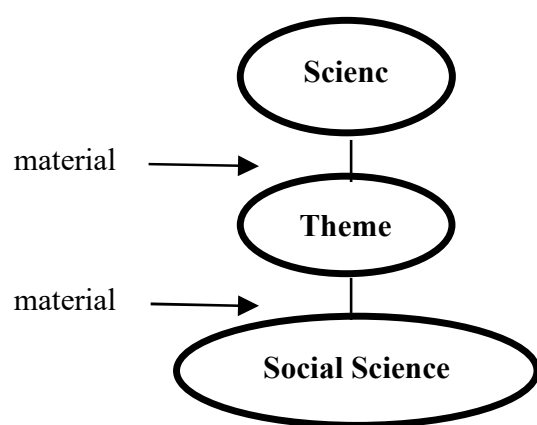

Figure 2. The process of determining themes in integrated learning

Note that in implementing integrated learning there are several integrated learning models that can be used. There are various integrated learning models, namely is: 


$\begin{array}{ll}\text { 1. FragmentedModel } & \text { 6.WebbedModel } \\ \text { 2.ConnectedModel } & \text { 7.ThreadedModel } \\ \text { 3.NestedModel } & \text { 8.IntegratedModel } \\ \text { 4.SequencedModel } & \text { 9.ImmersedModel } \\ \text { 5.Shared Model } & \text { 10. NetworkedModel }\end{array}$

Integrated learning models it is not entirely appropriate to be applied to every student, considering the different levels of education, the possibility of implementing it must also be adjusted to the level of education. According to the results of the study of PGSD (1997) by the development team, there are three integrated learning models that seem to be the most suitable or appropriate to be applied in our elementary schools, namely webbing, connected models, and integrated models. Observations were made atPercutSenior High School where the learning there also uses the three models above namely webbing, connected and integrated. In this case the model of integrated learning will be explained based on the consideration of the integrated model as a basis of a "to the point" curriculum planning, making it easy for less experienced teachers to understand.

\section{Methodology Research}

Through observations atPercut high school high schools, by observing a number of things in the learning carried out in the school, it can be seen that high school perceptions are conducted by integrated learning. It was admitted that indeed to implement integrated learning needed competent educators (teachers), because in planning integrated learning could not be done without thorough preparation but in the method sometimes one of the educators said that there could be situational learning meaning integrated learning in a situation but things it cannot be separated from the structure of integrated learning After making observations, one of the integrated learning models used by the school is the integrated model by way of integrating subjects. This integrated model views the curriculum as a kaleidoscope that interdisciplinary topics include overlapping concepts and designs and patterns that emerge. It was also explained that the Integrated learning model is that in order to create themes from several subjects, the teacher must be able to first select concepts from several subjects, then be linked in one theme which is the main subject of several subjects.Murfiahdescribes the pattern of the Integrated model (See Figure 3 below).

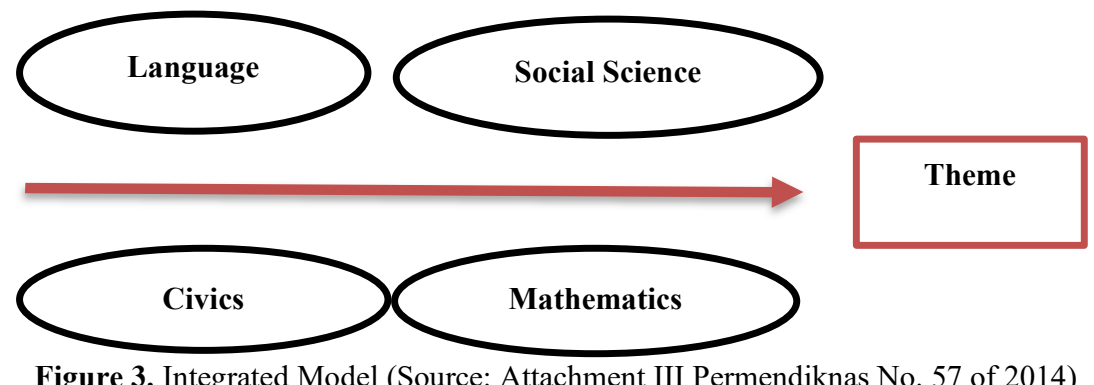

\section{Evaluating the Implementaionof Integrated Learning}


From the explanation above, it can be understood that integrated learning is learning that cannot be underrated because what needs to be known is that in its implementation, careful planning is needed. Moreover, evaluation is needed so that for this learning method, it can be seen where the advantages and disadvantages are in its application. In evaluating the implementation of integrated learning, it is expected that learning will have a positive impact on education. Evaluation means value, so to assess learning in such a way can be used in text or non-text, written or oral. If morethere was sufficient time, evaluation can also be done with a variety of evaluation methods. Although the evaluation carried out is non-textual as it only makes observations on the continuity of integrated learning, it nevertheless attempts to obtain, analyze, and interpret data about the learning process and outcomes of the students during the learning process. Therefore the evaluation carried out is an evaluation of process, in which this evaluation intends to assess the learning activities carried out by educators (teachers) and their students. The evaluation of learning outcomes from the learning process is carried out for the purpose of scoring the learning outcomes achieved by the determination of criteria that have been determined. Assessment of learning processes and outcomes are interrelated, because learning outcomes are the result of a learning process.

Figure 4. Examples of matrix evaluation of integrated learning

\begin{tabular}{lll}
\hline $\begin{array}{l}\text { Stages of Target } \\
\text { Process }\end{array}$ & \multicolumn{1}{c}{$\begin{array}{c}\text { Planning } \\
\text { How students participate in } \\
\text { determining related themes. }\end{array}$} & $\begin{array}{l}\text { Action } \\
\text { How is the activity of interaction } \\
\text { dynamics and students' thinking } \\
\text { abilities. } \\
\text { Behavior change / development } \\
\text { what happens to students. }\end{array}$ \\
& $\begin{array}{l}\text { How students react to plans } \\
\text { that have been prepared: }\end{array}$ & $\begin{array}{l}\text { Aspects of intellectual } \\
\text { cognition }\end{array}$ \\
- $\quad \begin{array}{l}\text { Social aspects } \\
\text { Personal and other } \\
\text { aspects as instructional } \\
\text { effects and nurturant } \\
\text { effects }\end{array}$ & \\
- Other aspects &
\end{tabular}

\section{Results}

Based on the results of the observations and evaluations made on the learning outcomes of the process, it was found that the learning is very effective because all students took part in the learning. In observation, students also become more open-minded by giving each other opinions or arguments against ongoing learning. So every aspect that has been designed by educators in learning can be achieved. Therefore it can be concluded that integrated learning invites teachers to be have a wider scope in planning learning and allowing students to become independent by being active in individuals or in groups. Therefore as an observer, the development of integrated learning is highly recommended.

\section{References}


[1] Anurrahman.2012. Belajar dan pembelajaran. Bandung: Penerbit CV Alfabeta

[2]Hj. UUM MURFIAH, M.Pd. 2017. Pembelajaran Terpadu .Bandung. PT. Refika Aditama

[4]Hernawan, Heri A dan Resmini ,Novi .2009.Pembelajaran Terpadu (Tematik).Jakarta :Direktorat Jendral Pendidikan Islam dan Departemen Agama RI

[5] Madjid, Abdul. 2014. Pembelajaran Tematik Terpadu. Bandung: PT Remaja Rosdakarya [6]Ngalimun, S.Pd., M.Pd.2017.Pembelajaran Terpadu.Yogyakarta. Prama Ilmu

[7] Ngalimun, 2013. Strategi Pembelajaran Berbasis PAIKEM. Banjarmasin: Pustaka Banua

[8] Sutrisno. 2010. Evaluasi dalam Pembelajaran Terpadu di Sekolah Dasar. Diunduh pada tanggal 16 Maret 2012 pada https://docs.google.com/gview?url=http://jurnal-teknologipendidikan.tp.ac.id/evaluasi-dalam-pembelajaran-terpadu-di-sekolah-

dasar.pdf\&embedded $=$ true

[9]Trianto, M.Pd. 2011. Model Pembelajaran Terpadu. Jakarta: PT. Bumi Aksara

[10]Trianto.2010.Mengembangkan model pembelajaran tematik .Jakarta : Prestasi pustaka

[11]Widodo, Sutrisno. 2010. Evaluasi Dalam Pembelajaran Terpadu di Sekolah Dasar. Jurnal Teknologi Pendidikan Vol.10 No. 1 Tahun April 2010. Portal Jurnal Ilmiah Universitas Negeri Surabaya.

(Online).

Diakses

di http://tp.jurnal.unesa.ac.id/.../tp1012Evaluasi_Dalam_Pembelajaran_Ter... 1 Juni 2012 pada 15:13 WIB 